\title{
MINAT MEMBACA MAHASISWA PROGRAM STUDI PG-PAUD FKIP UNTAN PONTIANAK
}

\author{
Halida \\ Dosen Prodi PG-PAUD. FKIP Untan. Pontianak \\ Email: halida.fkip@gmail.com
}

\begin{abstract}
Interest in reading is not something to be born just like that in a person, but something that belongs to someone for granted, but is something that can be developed. The general objective of this study was to determine the interest in reading students of PG-PAUD FKIP Untan. The results obtained from the research that is done on aspects of the feeling of pleasure with reading activities, students who receive a lower category, namely $11,26 \%$, being $33.52 \%$ and the category is quite high at $36,54 \%$. Higher category obtained a percentage of $18.68 \%$. That means a low student interest in reading for pleasure with the feelings aspects of the activity of reading. For the aspects of awareness of the importance of reading, students who receive lower categories, namely $9.07 \%, 12.64 \%$, and the category was quite high at $36.95 \%$. For high category obtained percentage of $41.35 \%$. Judging from the above data, the percentage of these were included in the analysis. Aspects aspects of attention to the activities of students obtained reading books that fall within the low at $7.56 \%$, currently $27.05 \%$, and the category is quite high at $50.13 \%$. Judging from the percentages then being included in the analysis.

It can be concluded that the interests of students Prodi PG-PAUD FKIP Untan still low. It is strongly advised Prodi PG-PAUD students in general and students of PG-PAUD force in 2013 specifically to continue to increase interest in reading by way penchant frequently visit the campus library and local libraries to read anything what.
\end{abstract}

Keyword : Students, Interest, Reading

\section{PENDAHULUAN}

Mahasiswa atau mahasiswi adalah sosok individu yang sedang menuntut ilmu di sebuah Perguruan Tinggi baik Negeri maupun Swasta. Mahasiswa yang berada di Perguruan Tinggi merupakan tonggak dari kemajuan suatu negara. Membaca merupakan sebuah aktivitas yang tidak asing bagi masyarakat. Bahkan kegiatan membaca sudah diperkenalkan sejak usia dini. Membaca adalah mengemukakan atau membunyikan rangkaian lambanglambang bahan tulis yang dilihatnya dari huruf menjadi kata, kemudian menjadi frasa, kalimat dan seterusnya.

Menurut Miles A Tingker dan Contasc dalam (Darmiyati, Zuchdi, 2007: 22) membaca adalah kegiatan melibatkan proses identifikasi dan proses mengingat suatu bahan bacaan yang disajikan sebagai rangsangan untuk membangkitkan pengalaman dan membentuk pengertian baru melalui konsep-konsep yang relevan yang telah dimiliki oleh pembaca.
Dengan membaca, kemampuan berpikir manusia akan semakin terasah dan berkembang, ilmu pengetahuanpun akan bertambah dan meningkatkan kualitas Sumber Daya Manusia (SDM).

Minat merupakan salah satu faktor psikis yang menyebabkan siswa membaca. Minat dapat berupa dorongan individu dalam memberi stimulus suatu kegiatan yang dilaksanakan untuk mencapai suatu tujuan yang hendak dicapai. Witherington (1999), berpendapat minat adalah kesadaran seseorang dalam sesuatu obyek seseorang, suatu soal atau situasi mengandung sangkut paut dengan dirinya. Pengetahuan atau informasi tentang seseorang atau suatu obyek pasti harus ada terlebih dahulu dapat minat obyek tadi. Selanjutnya Slameto (1995) menyatakan minat adalah kecenderungan jiwa yang tetap untuk memperhatikan dan mengenang beberapa aktivitas atau kegiatan. 
Seseorang yang berminat terhadap suatu aktivitas dan memperhatikan itu secara konsisten dengan rasa senang. Hal senada juga diungkapkan oleh Heri (1998) minat adalah suatu fungsi jiwa untuk dapat mencapai sesuatu yang merupakan kekuatan di dalam dan tampak di luar sebagai gerak-gerik. Dalam menjalankan fungsinya minat berhubungan erat dengan pikiran dan perasaan. Manusia memberi corak dan menentukan sesudah memilih dan mengambil keputusan. Perubahan minat memilih dan mengambil keputusan disebut keputusan kata hati.

Slamet, (2003:180) menyatakan bahwa minat adalah suatu rasa lebih suka dan rasa keterikatan pada suatu hal atau aktivitas, tanpa ada yang menyuruh. Selanjutnya, Sabri (2007:84) minat (interest) adalah suatu kecenderungan untuk selalu memperhatikan dan mengingat sesuatu secara terus menerus. Menurut Doyles Fryer dalam Nurkancana dan Sumartana (1986:229) menyatakan bahwa minat (interest) adalah gejala psikis yang berkaitan dengan objek atau aktivitas yang menstimulir perasaan senang pada individu. Saleh, (2008:261) bahwa "minat seseorang terhadap sesuatu adalah kecenderungan hati yang tinggi, gairah atau keinginan seseorang terhadap sesuatu jika siswa melihat sesuatu yang akan memberikan manfaat, mereka akan memperoleh kepuasaan dan siswa akan berminat pada hal tersebut. Crow dan Crow dalam Ramayulis (1994:175) mengatakan bahwa minat itu diartikan sebagai kekuatan pendorong yang menyebabkan individu memberikan perhatian kepada seseorang, sesuatu, atau kepada aktivitas-aktivitas tertentu. Hardjana dalam Lockmono (1995), minat merupakan kecenderungan hati yang tinggi terhadap sesuatu yang timbul karena kebutuhan, yang dirasa atau tidak dirasakan atau keinginan hal tertentu. Minat dapat diartikan kecenderungan untuk dapat tertarik atau terdorong untuk memperhatikan seseorang sesuatu barang atau kegiatan dalam bidangbidang tertentu.

Secara umum minat dapat diartikan sebagai suatu kecenderungan yang menyebabkan seseorang berusaha untuk mencari ataupun mencoba aktivitas-aktivitas dalam bidang tertentu. Minat juga diartikan sebagai sikap positif terhadap aspek-aspek lingkungan. Ada juga yang mengartikan minat sebagai kecenderungan yang tetap untuk memperhatikan dan menikmati suatu aktivitas disertai rasa senang. Meichati dalam Ramayulis (1994) mengartikan minat adalah perhatian yang kuat, intensif, dan menguasai individu secara mendalam untuk tekun melakukan suatu aktivitas.

Berdasarkan pada definisi di atas maka minat merupakan keadaan dimana seseorang menunjukkan keinginan ataupun kebutuhan yang ada dalam dirinya, hal tersebut dapat terlihat dari ciri-ciri yang nampak pada diri mereka dan cirri tersebut memunculkan arti yang terkadung didalamnya. Minat timbul tidak secara tiba-tiba atau spontan, melainkan timbul akibat dari partisapasi, pengalaman, kebiasaan pada waktu belajar untuk bekerja. Dengan demikian minat akan selalu berkaitan dengan kebutuhan dan keinginan. Oleh karena itu yang penting bagaimana menciptakan kondisi tertentu agar siswa itu selalu butuh dan ingin terus belajar. Minat merupakan suatu sikap batin dari dalam diri seseorang yang merupakan suatu perhatian khusus terhadap suatu hal tertentu yang tercipta dengan penuh kemauan dan perasaan senang yang timbul dari dorongan batin seseorang. Minat dapat dikatakan sebagai dorongan kuat bagi seseorang untuk melakukan segala sesuatu dalam mewujudkan pencapaian tujuan dan cita-cita yang menjadi keinginannya.

\section{Pengertian Membaca}

Dalam mencari informasi dan memperluas cakrawala pengetahuan, membaca mempunyai arti penting. Dalam studi ilmu pengetahuan, hampir semuanya diperoleh dengan membaca. Apabila seseorang bisa membaca dia akan dapat mengenal kata-kata, gambar-gambar, mengetahui, mengerti dan menghayati ide yang dikemukakan oleh pengarang yang terdapat dalam suatu bacaan. Membaca adalah proses untuk memperoleh pengertian dari kombinasi beberapa huruf dan kata. Membaca merupakan proses untuk mengenal kata dan memadukan arti kata dalam kalimat dan struktur bacaan. Kangnas. 2013. Pengertian Membaca Menurut Para Ahli. (Online), (http:// mbegedut. 
blogspot.co.id/2013/04/ pengertian-membacamenurut-para-ahli.html), diakses 4 Juni 2016.

Dari pengertian ini terungkap bahwa kegiatan membaca bukanlah semata-mata proses visual saja, tetapi melibatkan dua macam informasi, yaitu pertama yang datangnya dari apa yang ada di depan mata kita, dan yang kedua datangnya dari belakang mata kita. Hasil akhir dari proses membaca adalah seseorang mampu membuat intisari dalam bacaan. Membaca merupakan kemampuan dan keterampilan untuk membuat suatu penafsiran terhadap bahan yang dibaca. Yang dimaksud dengan kepandaian membaca tidak hanya menginterpretasikan huruf-huruf, gambar-gambar, dan angka-angka saja, tetapi yang lebih luas daripada itu ialah kemampuan seseorang untuk dapat memahami makna dari suatu yang dibacanya. Proses membaca itu sebenarnya tidak ubahnya dengan proses ketika seseorang sedang berpikir dan bernalar. Dalam proses membaca ini, terlihat aspekaspek berpikir seperti, mengingat, memahami, membeda-bedakan, membandingkan, menemukan, mengorganisasikan, dan pada akhirnya menerapkan apa-apa yang terkandung dalam bacaan. Jadi, dalam membaca diperlukan intelektual yang tinggi.

Selain itu, membaca merupakan suatu bentuk komunikasi antara pembaca dan media cetak yang dibacanya sebagai wakil dari penulisnya. Suatu komunikasi yang baik menuntut suatu pengalaman linguistik yang erat hubungannya dengan segi-segi ekspresi. Karena itulah membaca merupakan kegiatan intelektual yang dapat mendatangkan pandangan, sikap, dan tindakan yang positif.

Membaca adalah aktivitas yang kompleks dan melibatkan berbagai faktor yang datangnya dari dalam diri pembaca dan faktor luar. Selain itu, membaca juga dapat dikatakan sebagai jenis kemampuan manusia sebagai produk belajar dari lingkungan, dan bukan dari kemampuan yang bersifat instingtif atau naluri yang dibawa sejak lahir. Oleh karena itu, proses membaca dilakukan oleh orang yang dapat membaca merupakan usaha mengolah dan menghasilkan sesuatu melalui penggunaan membaca.
Dapat disimpulkan bahwa membaca merupakan proses aktivitas komunikasi yang kompleks. Membaca bertujuan untuk melihat, memahami isi atau makna dan memperoleh pesan yang hendak disampaikan penulis melalui media kata-kata atau bahasa tulis sehingga diperoleh pemahaman terhadap bacaan. Melalui membaca, informasi dan pengetahuan yang berguna bagi kehidupan dapat diperoleh. Orang yang melakukan aktivitas tentunya mempunyai tujuan yang ingin dicapai, demikian juga dalam kegiatan membaca.

\section{Tujuan Membaca}

Macam-macam tujuan membaca yaitu: (1) kesenangan; (2) menyempurnakan membaca nyaring; (3) menggunakan strategi tertentu; (4) memperbaharui pengetahuannya tentang suatu topik; (5) mengaitkan informasi yang baru dengan informasi yang telah diketahuinya; (6) memperoleh informasi untuk laporan lisan atau tertulis; (7) mengkonfirmasikan atau menolak prediksi; (8) menampilkan suatu eksperimen atau mengaplikasikan informasi yang diperoleh dari suatu teks dalam cara lain dan mempelajari tentang struktur teks; (9) menjawab pertanyaan-pertanyaan yang spesifik. Seseorang yang membaca dengan suatu tujuan, cenderung lebih memahami dibandingkan dengan orang yang tidak mempunyai tujuan. Tujuan utama dalam membaca adalah untuk mencari serta memperoleh informasi, mencangkup isi, memahami makna bacaan.

Tujuan utama dalam membaca adalah untuk mecari serta memperoleh informasi, mencakup isi, memahami makna bacaan. Makna, arti (meaning) erat sekali berhubungan dengan maksud tujuan, atau intensif kita dalam membaca. Beberapa hal yang penting dalam membaca, sebagai berikut:

a. Membaca untuk menemukan atau mengetahui penemuan-penemuan yang telah dilakukan oleh tokoh, apa-apayang telah dibuat tokoh, apa yang terjadi pada tokoh khusus, atau untuk memecahkan masalah-masalah yang dibuat oleh tokoh. Membaca untuk mengetahui mengapa hal itu merupakan topik yang baik dan menarik, masalah yang terdapat dalam 
cerita, apa-apa yang dipelajari atau yang dialami tokoh, dan merangkumkan hal-hal yang dilakukan oleh tokoh untuk mencapai tujuannya. Membaca seperti ini disebut membaca untuk memperoleh ideide utama (reading for main ideas).

b. Membaca untuk menemukan atau mengetahui apa yang terjadi pada setiap bagian cerita, apa yang terjadi mula-mula pertama, kedua, dan ketiga/ seterusnya. Setiap tahap dibuat untuk memecahkan suatu masalah, adegan-adegan dan kejadian-kejadian buat dramatisasi. Ini disebut membaca untuk mengetahui urutan dan susunan, organisasi cerita (reading for sequence organization).

c. Membaca untuk menemukan serta mengetahui mengapa para tokoh merasakan seperti cara mereka itu, apa yang hendak diperlihatkan oleh pengarang kepada para pembaca, mengapa para tokoh berubah, kualitas-kualitas yang dimiliki para tokoh yang membuat mereka berhasil atau gagal. Membaca ini disebut membaca untuk menyimpulkan/membaca inferensi (reading for inference).

d. Membaca untuk menemukan serta mengetahui apa-apa yang tidak biasa, tidak wajar mengenai seorang tokoh,apa yang lucu dalam cerita, dan apakah cerita itu benar atau tidak benar. Membaca ini disebut membaca untuk mengelompokkan/ membaca untuk menglasifikasikan (reading for classify).

e. Membaca untuk menentukan apakah tokoh berhasil atau hidup dengan ukuranukuran tertentu, apakah ingin berbuat seperti yang diperbuat oleh tokoh, atau bekerja seperti cara tokoh bekerja dalam cerita itu. Membaca ini disebut membaca menilai/ membaca mengevalusi (reading for evaluate).

f. Membaca untuk menemukan bagaimana caranya tokoh berubah, bagaimana hidupnya berubah dari kehidupan yang kita kenal, bagaimana dua cerita mempunyai persamaan, dan bagaimana tokoh menyerupai pembaca. Membaca ini disebut membaca untuk memperbandingkan

atau mempertentangkan (reading for compare or contrast), menurut Anderson dalam Tarigan (2008)

\section{Faktor-faktor dalam Membaca}

\section{a. Faktor-faktor yang Mempengaruhi} Minat Baca

Ada beberapa faktor yang mampu mendorong bangkitnya minat baca masyarakat. Faktor-faktor tersebut adalah; (1) rasa ingin tahu yang tinggi atas fakta, teori, prinsip, pengetahuan dan informasi, (2) keadaan lingkungan fisik yang memadai, dalam arti tersedianya bahan bacaan yang menarik, berkualitas dan beragam, (3) keadaan lingkungan sosial yang kondusif, maksudnya adanya iklim yang selalu dimanfaatkan dalam waktu tertentu untuk membaca, (4) rasa haus informasi, rasa ingin tahu, terutama yang aktual, dan (5) berprinsip hidup bahwa membaca merupakan kebutuhan rohani.

$$
\text { Selanjutnya Tarigan (2008) }
$$

mengungkapkan faktor-faktor yang mempengaruhi turunnya minat membaca adalah.

\section{a. Faktor Lingkungan}

Faktor lingkungan sangatlah berpengaruh terhadap minat baca seseorang. Apabila budaya membaca diterapkan sejak dini, maka ketika remaja dan dewasa nantinya juga akan melakukan hal demikian. Dan untuk selanjutnya, anak-anak tersebut akan mengerti betapa pentingnya memiliki sikap minat terhadap membaca. Namun apabila dalam lingkungan keluarga tidak atau bahkan tidak pernah menerapkan atau mendukung budaya membaca, dan si anak lebih dikenalkan dengan teknologi yang ada, maka anak tersebut tidak akan memiliki sikap minat terhadap membaca. b. Faktor Kepribadian

Minat baca seseorang pastilah dipengaruhi oleh kepribadian diri dari diri orang tersebut. Jika dalam diri mereka tidak terdapat minat membaca, maka orang tersebut tidak akan mengerti akan pentingnya membaca. Akan tetapi, jika dalam diri mereka terdapat kesadaran akan pentingnya membaca sebagai penambah pengetahuan, maka mereka akan menerapkan budaya membaca dengan paling tidak membaca suatu buku.

c. Faktor Ekonomi 
Faktor ekonomi juga dapat membuat seseorang mengalami penurunan minat baca. Jika keadaan ekonomi seseorang itu menengah kebawah ataupun sedang, kebanyakan dari mereka mempunyai minat baca yang rendah. Hal itu dapat terjadi karena bagi mereka yang ekonominya lemah tersebut, menganggap bahwa membeli buku untuk bahan bacaan membuat kesulitan yang berarti dalam menyisihkan uang. Berbeda dengan seseorang yang ekonominya menengah keatas atau mapan, mereka tidak mengalami kesulitan untuk membeli buku.

Bastino (2011) mengungkapkan membaca mesti dibina sejak usia dini. Untuk membina minat baca dipengaruhi oleh faktor intrisik dan ekstrinsik.

a. Faktor Intrinsik.

Upaya pembinaan dan peningkatan minat baca secara sistematis merupakan salah satu tugas dan tanggung jawab perpustakaan di samping aspek-aspek lainnya. Dalam melaksanakan pembinaan dan peningkatan minat baca banyak kendala-kendala yang terasa dari dalam perpustakaan sendiri yang disebut sebagai faktor intrinsik.

b. Faktor Ekstrinsik

Selain faktor-faktor intrinsik, faktor-faktor ekstrinsik juga mempengaruhi pembinaan dan peningkatan minat baca. Yang dimaksud dengan faktor-faktor ekstrinsik adalah faktorfaktor yang berada di luar perpustakaan, namun mempengarui pembinaan dan pengembagan minat baca yang menjadi salah satu tugas dan tanggung jawab perpustakaan.

Ada tiga alasan pentingnya membaca.

Pertama, membaca merupakan suatu alat komunikasi yang sangat diperlukan dalam suatu masyarakat berbudaya. Kedua, bahan bacaan yang dihasilkan dalam setiap kurun zaman dalam sejarah sebagian besar dipengaruhi oleh latar belakang sosial tempatnya berkembang itu. Ketiga, sepanjang masa sejarah yang terekam, membaca telah membuahkan dua kutub yang amat berbeda.

Zuchdi (2007) menyatakan membaca adalah jendela dunia, dengan membaca dapat mengetahui sesuatu yang tidak dapat dilakukan secara langsung. Membaca merupakan kegiatan berbahasa yang bersifat resesif (menerima atau menyerap). Setiap individu memiliki kemampuan membaca yang berbeda. Untuk mengoptimalkan keterampilan membaca seseorang, diperlukan peningkatan minat membaca. Karena membaca dapat memberikan dampak positif dalam pengembangan diri seseorang.

\section{METODE}

Penelitian ini bertujuan untuk mengetahui minat membaca mahasiswa angkatan 2013 baik mahasiswa Reguler A maupun mahasiswa PP-APK-PT Program studi PG-PAUD FKIP Untan.

Tempat dan Waktu Penelitian:

1. Penelitian ini dilakukan pada Program Studi PG-PAUD FKIP Untan. Terletak di komplek FKIP Untan jalan Prof. Dr. Hadari Nawawi. Pontianak.

2. Waktu Penelitian. Penelitian dilakukan dari bulan Agustus sampai dengan November 2016.

Metode yang digunakan dalam penelitian ini adalah adalah metode deskriptif. Metode deskriptif adalah metode dalam meneliti sekelompok manusia, suatu objek, suatu set kondisi, suatu sistem pemikiran, ataupun suatu kelas peristiwa pada masa sekarang.

Subjek yang terlibat dalam penelitian ini adalah mahasiswa Program Studi PG-PAUD FKIP Untan angkatan 2013 semester VII (tujuh) sebanyak 52 responden yang terdiri dari mahasiswa Reguler A dan mahasiswa PPAPK-PT.

Alat pengumpulan data dalam penelitian ini adalah berupa pernyataan yang menyangkut tentang minat membaca pada mahasiswa Program Studi PG-PAUD FKIP Untan. Metode analisis yang digunakan dalam penelitian ini adalah Analisis Deskriptif Persentase. Deskriptif persentase ini diolah dengan cara frekuensi dibagi dengan jumlah responden dikali 100 persen, seperti dikemukan Sugiyono (2006) adalah sebagai berikut

$P=\frac{f}{N} \times 100 \%=\ldots \ldots \%$

Keterangan:

$P \quad=$ persentase

$\mathrm{f} \quad=$ frekuensi

$\mathrm{N} \quad=$ jumlah responden 
$100 \%=$ bilangan tetap

Penghitungan deskriptif persentase ini mempunyai langkah-langkah sebagai berikut:

1. Memeriksa dan mengoreksi jawaban kuesioner dari responden;

2. Menghitung frekuensi jawaban responden;

3. Jumlah responden keseluruhan;

4. Memasukkan ke data yang dihitung kemudian memasukkan ke dalam rumus.

\section{HASIL DAN PEMBAHASAN}

\section{Hasil Penelitian}

Berdasarkan hasil analisis angket tentang Minat Membaca Mahasiswa Program Studi
PG-PAUD FKIP Untan, yang terdiri dari minat membaca mahasiswa Program Studi PGPAUD FKIP Untan dalam aspek perasaan senang terhadap buku bacaan, minat membaca mahasiswa Program Studi PG-PAUD FKIP Untan dalam aspek kesadaran akan manfaat membaca buku, minat membaca mahasiswa Program Studi PG-PAUD FKIP Untan dalam aspek perhatian dengan kegiatan membaca.

Untuk menjawab semua aspek di atas, akan diuraikan di bawah ini

Di bawah ini disajikan dalam bentuk tabel dan grafik kemudian dianalisa dalam bentuk deskriptif tentang hasil Minat Membaca Mahasiswa Prodi PG-PAUD FKIP Untan.

Keterangan:

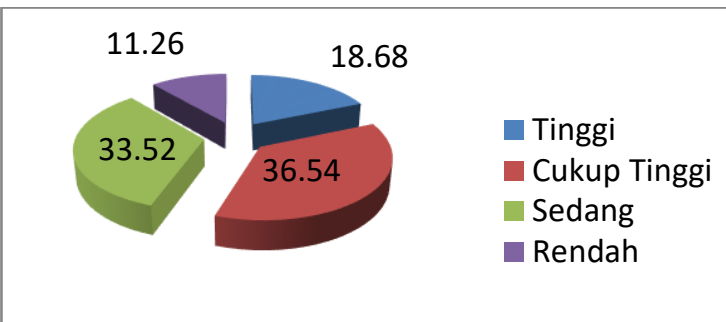

\section{Diagram 1}

Minat membaca mahasiswa program studi pg-paud fkip untan Aspek perasaan senang dengan kegiatan membaca

$$
\begin{array}{ll}
\text { Tinggi } & =66,67-100 \\
\text { Sedang } & =33,34-66,66 \\
\text { Kurang } & =0-33,33
\end{array}
$$

Untuk aspek perasaan senang dengan kegiatan membaca, mahasiswa yang memperoleh kategori rendah yaitu 11, 26\%, sedang $33,52 \%$ dan kategori cukup tinggi sebesar 36, 54\%. Untuk kategori tinggi diperoleh persentasi sebesar 18,68\%. Dilihat dari data di atas yang masuk kategori tinggi di bawah 50\%, hal ini menandakan bahwa $18,68 \%$ masuk dalam analisa rendah. Maksudnya mereka kurang hobby dalam membaca, kurang senang dalam membaca buku apasaja, mahasiswa menganggap kegiatan membaca merupakan sesuatu yang membosankan, kegiatan membaca bagi mahasiswa bukan merupakan kebutuhan, kemana-mana mereka jarang membawa buku, mahasiswa lebih menyenangi nonton $\mathrm{TV}$, main HP dan jalan-jalan. 


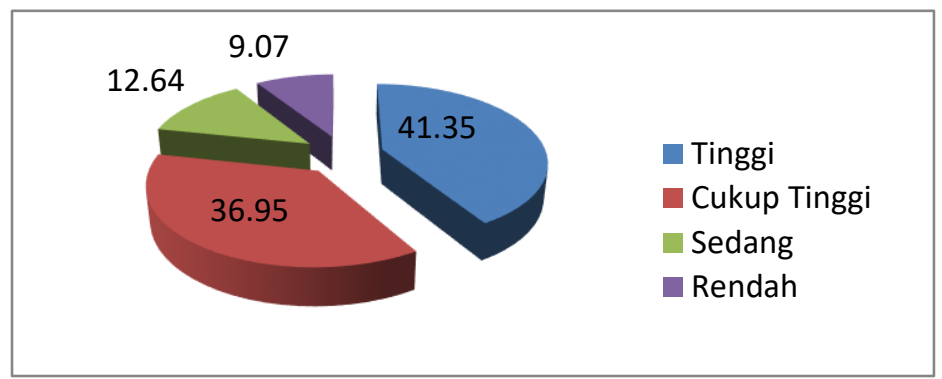

\section{Diagram 2 \\ Minat Membaca Mahasiswa Program Studi PG-PAUD FKIP Untan dalam Aspek Kesadaran akan Manfaat Membaca Buku.}

Untuk aspek kesadaran akan manfaat membaca buku, mahasiswa yang memperoleh kategori rendah yaitu $9,07 \%$, sedang $12,64 \%$ dan kategori cukup tinggi sebesar $36,95 \%$. Untuk kategori tinggi diperoleh persentasi sebesar $41,35 \%$. Dilihat dari data di atas, hasil persentase ini masuk dalam analisa sedang. Artinya mahasiswa merasa kehilangan informasi jika tidak membaca dalam sehari, mahasiswa merasakan manfaat dengan membaca dan membaca merupakan jembatan ilmu pengetahuan. Selanjutnya mahasiswa merasa dengan membaca buku inspirasi mereka terbuka, mahasiswa sering mencari mencari informasi-informasi yang berguna dengan browsing maupun searching internet. Dengan membaca banyak ilmu dan wawasan yang diperoleh mahasiswa, dengan mengetahui manfaat membaca mahasiswa mengetahui perkembangan dunia.

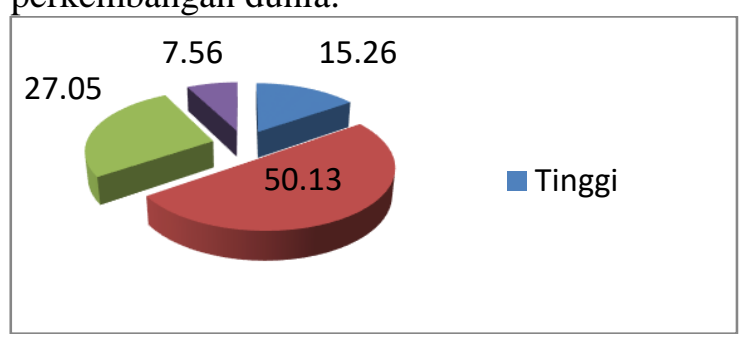

\section{Diagram 3 \\ Minat membaca mahasiswa Program Studi PG-PAUD FKIP Untan dalam aspek perhatian dengan kegiatan membaca buku.}

Aspek aspek perhatian dengan kegiatan membaca buku diperoleh mahasiswa yang masuk dalam kategori rendah yaitu $7,56 \%$, sedang $27,05 \%$ dan kategori cukup tinggi sebesar $50,13 \%$. Dilihat dari persentase maka masuk dalam analisa sedang. Artinya mahasiswa menyempatkan diri membaca buku pagi, siang, sore dan malam hari walau sebentar. Untuk kategori tinggi diperoleh persentasi sebesar 15,35\%. Dilihat dari data di atas, hasil persentase ini masuk dalam analisa rendah. Makna dari hasil analisa rendah adalah bahwa dalam sehari mereka kadang membaca kadang tidak itu pun cuma satu kali dan sebentar. Mahasiswa lebih banyak menyempatkan waktu untuk main HP sesama mereka daripada membaca. Dalam seminggu mahasiswa jarang berkunjung ke perpustakaan lebih dari 3 kali. Mahasiswa malas membaca walau ada waktu. Setiap hari frekuensi mereka membaca berdurasi 5- 10 menit saja. Untuk jumlahnya mereka mampu membaca berkisar 2-4 lembar saja.

\section{Pembahasan}

\section{Aspek perasaan senang dengan kegiatan membaca}

Dilihat dari hasil yang diperoleh tentang perasaan senang dengan kegiatan membaca yang masih rendah, sesuai dengan temuan yang diungkapkan oleh Data dalam dokumen UNDP dalam Human Development Report 2000, bahwa angka melek huruf orang dewasa di Indonesia hanya 65,5 persen. Sedangkan Malaysia sudah mencapai 86,4 persen, dan negara-negara maju seperti Australia, Jepang, Inggris, Jerman, dan AS 
umumnya sudah mencapai 99,0 persen. Dalam hal pendidikan, survei The Political and Economic Risk Country (PERC), sebuah lembaga konsultan di Singapura, pada akhir 2001, menempatkan Indonesia di urutan ke-12 dari 12 negara di Asia yang diteliti. Berdasarkan survei UNESCO pada tahun 2011. Hasil survey lembaga UNESCO (United Nation Education Society and Cultural Organization) ada tahun 2011, fakta berbicara bahwa indeks membaca masyarakat Indonesia betul-betul rendah yaitu baru sekitar 0,001. Artinya dari seribu penduduk, hanya ada satu orang yang masih memiliki minat baca tinggi. Angka ini masih sangat jauh dibandingkan dengan angka minat baca di Amerika dan Singapura, apalagi Jepang. Amerika memiliki indeks membaca 0,45 dan Singapura memiliki indeks 0,55. Jepang memiliki indeks 17 koma sekian. Bahkan budaya baca masyarakat Indonesia berada di urutan ke-38 dari 39 negara dan merupakan yang paling rendah di kawasan ASEAN.

Menurut data yang dikeluarkan Badan Pusat Statistik (BPS) tahun 2006, menunjukkan bahwa masyarakat lebih banyak tertarik dan memilih untuk menonton TV $(85,9 \%)$ dan atau mendengarkan radio $(40,3 \%)$ ketimbang membaca koran $(23,5 \%)$. Hal ini diperkuat oleh oleh pendapat Broughton dalam Tarigan (2008: 12-13) minat membaca bisa turun karena dipengaruhi faktor lingkungan, faktor kepribadian dan faktor ekonomi.

Faktor lingkungan sangatlah berpengaruh terhadap minat baca seseorang. Apabila budaya membaca diterapkan sejak dini, maka ketika remaja dan dewasa nantinya juga akan melakukan hal demikian. Faktor Kepribadian, minat baca seseorang pastilah dipengaruhi oleh kepribadian diri dari diri orang tersebut. Jika dalam diri mereka tidak terdapat minat membaca, maka orang tersebut tidak akan mengerti akan pentingnya membaca. Faktor ekonomi juga dapat membuat seseorang mengalami penurunan minat baca. Jika keadaan ekonomi seseorang itu menengah ke bawah ataupun sedang, kebanyakan dari mereka mempunyai minat baca yang rendah. Hal itu dapat terjadi karena bagi mereka yang ekonominya lemah tersebut, menganggap bahwa membeli buku untuk bahan bacaan membuat kesulitan yang berarti dalam menyisihkan uang. Berbeda dengan seseorang yang ekonominya menengah $\mathrm{ke}$ atas atau mapan, mereka tidak mengalami kesulitan untuk membeli buku.

\section{Aspek kesadaran manfaat membaca buku.}

Untuk aspek kesadaran akan banyaknya manfaat ilmu yang diperoleh dengan membaca, mahasiswa memperoleh kategori sedang. Mereka sadar bahwa membaca merupakan gerbang ilmu pengetahuan. Dengan membaca individu tidak akan ketinggalan informasi, dengan membaca dunia seperti dalam genggaman. Membaca merupakan kebutuhan. Kenyataan terssebut sesuai dengan pendapat Tarigan (2008) yang mengatakan bahwa manfaaat membaca dapat menghilangkan kecemasan dan kegundahan; terhalang masuk ke dalam kebodohan; kebiasaan membaca membuat orang terlalu sibuk untuk bisa berhubungan dengan orang-orang malas dan tidak mau bekerja; dengan sering membaca, orang bisa mengembangkan keluwesan dan kefasihan dalam bertutur kata; membantu mengembangkan pemikiran dan menjernihkan cara berpikir; meningkatkan pengetahuan seseorang dan meningkatkan memori dan pemahaman; dengan membaca, orang mengambil manfaat dari pengalaman orang lain: kearifan orang bijaksana dan pemahaman para sarjana; dengan sering membaca, orang mengembangkan kemampuannya; baik untuk mendapat dan memproses ilmu pengetahuan maupun untuk mempelajari berbagai disiplin ilmu dan aplikasinya dalam hidup; membaca membantu seseorang untuk menyegarkan pemikirannya dari keruwetan dan menyelamatkan waktunya agar tidak sia-sia; dengan sering membaca, orang bisa menguasai banyak kata dan mempelajari berbagai tipe dan model kalimat; lebih lanjut lagi ia bisa meningkatkan kemampuannya untuk menyerap konsep dan untuk memahami apa yang tertulis "diantara baris demi baris" (memahami apa yang tersirat). 


\section{Aspek perhatian dengan kegiatan membaca}

Dalam aspek perhatian dalam kegiatan membaca ditemukan masih rendah seperti tidak menyiapkan waktu untuk membaca, belum maksimal menggunakan waktu luang. Kunjungan ke perpustakaan juga masih jarang dalam semingu. Literatur baru dan pengarang buku terkenal kurang menggugah minat mahasiswa untuk membaca. Satu hari mereka membaca hanya 2 sampai 3 lembar. Harian Kompas, terbitan 12 Juni 2009. Minat dan perhatian mahasiswa untuk membaca berbeda dengan mahasiswa sebelum era modern. Harian tersebut berisi tentang banyaknya literatur dan penerbit buku tidak mempengaruhi minat perhatian terhadap kegiatan membaca mahasiswa. Sebelum era modern, saat fasilitas masih terbatas para mahasiswa mempunyai semangat dan motivasi yang tinggi untuk membaca. Pembangunan perpustakaan dan pembelian referensi yang banyak nampaknya kurang menyentuh perhatian mahasiswa terhadap kegiatan membaca literatur yang berkaitan dengan mata kuliah yang diambil.

\section{DAFTAR RUJUKAN}

Arikunto, Suharsimi. 2006. Prosedur Penelitian Suatu Pendekatan Praktek, Edisi Revisi VI, Jakarta: Rineka Cipta.

Asrori, M. 2015. Perkembangan Peserta Didik. Pontianak. Untan Press

Azam, Syukur Rammatullah. 2005.

Problematika Anak Kampus. Qurani Media Pustaka: Yogyakarta

Chaplin, J. P. 2008. Kamus Psikologi Lengkap. Jakarta: PT Raja Grafindo.

De Porter, Bobbi \& Mike Hernachi. 2003. Quantum Learning: Membiasakan Belajar Nyaman dan Menyenangkan. Kaifa: Bandung

Heri, P. 1998. Pengantar Perilaku Manusia. Jakarta : EGC.

Loekmono. 1994 Belajar Bagaimana Belajar. Jakarta: BPK Gunung Mulia.

\section{SIMPULAN DAN SARAN Simpulan}

Berdasarkan hasil analisis data dan pembahasan, dapat diambil kesimpulan umum bahwa minat membaca mahasiswa program studi PG-PAUD FKIP Untan angkatan 2013 tergolong rendah. Untuk kesimpulan pertanyaan khusus akan diuraikan di bawah berikut ini:

1. Minat membaca mahasiswa Program Studi PG-PAUD FKIP Untan dalam aspek perasaan senang dengan kegiatan membaca masih rendah.

2. Minat membaca mahasiswa Program Studi PG-PAUD FKIP Untan dalam aspek kesadaran manfaat membaca buku masuk kategori sedang.

3. Minat membaca mahasiswa Program Studi PG-PAUD FKIP Untan dalam aspek perhatian dalam kegiatan membaca buku masih rendah.

\section{Saran}

Melengkapi fasilitas yang masih terbatas untuk mahasiswa. Memotivasi semangat untuk membaca. Pembangunan perpustakaan dan pembelian referensi yang banyak nampaknya kurang menyentuh perhatian mahasiswa terhadap kegiatan membaca literatur yang berkaitan dengan mata kuliah yang diambil.

Nurkancana, Wayan dan Sumartana. 1986. Evaluasi Pendidikan. Surabaya : Usaha Nasional

Ramayulis. 1994. Dasar-Dasar Keterampilan Berbahasa Indonesia. Surakarta: Universitas Sebelas Maret Press.

Sabri, Alisuf. 2000. Psikologi Pendidikan. Jakarta : Pedoman Ilmu Jaya Shaleh, Sardiman, 2007. Interaksi dan Motivasi Belajar Mengajar. Jakarta: PT. Grasindo Persada

Slameto. 1995. Belajar dan Faktor-faktor yang Mempengaruhinya. Cet. II; Jakarta: Rineka Cipta.

Tarigan, Henry Guntur. 2008. Membaca Sebagai Suatu Keterampilan Berbahasa. Bandung: Angkasa Bandung Sudarsana Undang, Bastino. 2011. Pembinaan Minat Baca. Jakarta: UT 
Witherington, H. C. 1999. Psikologi

Pendidikan. Jakarta : Aksara Baru
Zuchdi, Darmiyati. 2007. Strategi Meningkatkan Kemampuan Membaca.

Sumber lain yang mendukung:

Kangnas. 2013. Pengertian Membaca Menurut Para Ahli. (Online), (http:// mbegedut. blogspot.co.id/2013/04/ pengertianmembaca-menurut-para-ahli.html), diakses 4 Juni 2016. 